\title{
The Analysis Optimization Analysis of Budget Absorption of State University Operational Assistance Funds (BOPTN) in FEB, FISIP, and FH Lambung Mangkurat University
}

Jupriadi ${ }^{*}$, Aslamiah, Suriansyah

Education Management Masters Program, Lambung Mangkurbat University, Banjarmasin, Indonesia

\begin{tabular}{|c|c|}
\hline ARTICLE INFO & A B STRACT \\
\hline \multirow[t]{2}{*}{$\begin{array}{l}\text { Article history } \\
\text { Received: June } \\
\text { Revised: August } \\
\text { Accepted: September } \\
\text { Keywords: BOPTN, } \\
\text { Optimization, Budget } \\
\text { Absorption. }\end{array}$} & $\begin{array}{l}\text { This study aims to describe the optimization model of BOPTN budget absorption } \\
\text { on FEB, FISIP and FH ULM budget year } 2016 \text { to } 2018 \text { and identify constraints } \\
\text { faced in optimizing the budget absorption. This research is a qualitative research } \\
\text { with descriptive methods and quantitative data presentation. The research results of } \\
\text { budget absorption in FEB, FISIP, and FH ULM Banjarmasin units from 20I6 S / } \\
\text { D in } 2018 \text { experienced a significant increase in BOPTN fund absorption } \\
\text { optimization. This is intended from the percentage numbers in the recapitulation } \\
\text { of budget realization in the FEB, FISIP, and ULM Banjarmasin work units which } \\
\text { reached I00\% in } 2017 \text { and 20I8. Employee competencies and budget absorption } \\
\text { performance have a unidirectional relationship, if employee competencies are } \\
\text { higher, the higher also the level of performance of budget absorption. Similarly, the } \\
\text { role of information technology is so important in the budget process. Maintenance } \\
\text { and repair of hardware and software that are compiled in a comprehensive, clear } \\
\text { and periodic manner. }\end{array}$ \\
\hline & $\begin{array}{l}\text { (C) (1) () } 2019 \text { The Authors. Journal of K6, Education, and Management } \\
\text { (j-K6EM). ISSN: 2580-2135. Published by Graduated Program of } \\
\text { Educational Management, Universitas Lambung Mangkurat, }\end{array}$ \\
\hline
\end{tabular}

*Correspondence: Jupriadi; E-mail: jupriadi@ulm.ac.id 


\section{Introduction}

Sources of funds in universities are obtained through the government, the community, and foreign parties. Sources of funds originating from the Government, in the form of routine budgets and development budgets and subsidies have been regulated according to applicable laws. The funds obtained from the community can come from Education Development Donations (SPP), university admission selection costs, the result of collaboration between universities and related parties in accordance with their roles and functions, product sales generated from the organization of universities, donations, and grants from individuals, government institutions, and nongovernment organizations government and acceptance from other communities (Suharsimi, 2013). The receipt of funds and the use of funds originating from abroad are regulated based on the provisions of the applicable legislation. The receipt of funds originating from the community is regulated by the principle of not seeking profits to increase income. For universities, autonomy in the field of finance organized by the government includes direct authority in the use of funds originating from the community. The source of education costs for state universities in Indonesia, especially in the form of Public Service Agencies (BLU), according to law number 23 of 2005 concerning financial management of public service bodies, in article I4 stated that the total income comes from the State Budget (APBN) income derived from services provided to other communities or entities, bound grants obtained from the community or other entities (Saifuddin, 2007).

The intended APBN is in the form of pure rupiah and Non-Tax State Revenues (PNBP). PNBP comes from students (parents) in the form of community development contributions and other education fees, including results obtained from services provided to the community (kemekeu).

Today, the need for education is increasing based on increasingly high development progress. Although the participation of higher education in Indonesia continues to increase, they are relatively far behind the neighboring countries. The high cost of education is a serious complaint among the people (Bastian, 2006).

In this case, the government has attempted to anticipate the high cost of education by establishing no increase in tuition fees (SPP) and implementing the Single Tuition System (UKT) in public universities that are effective since the 20I2/2013 academic year.

BOPTN is a cost aid provided by the government to finance deficiencies in operational costs that are in accordance with minimum service standards in state universities due to an increase in the contribution of education (Republic of Indonesia, 2016). Which is where the BOPTN is provided by the government by allocating it in the state's income and expenditure budget. BOPTN is allocated for education costs, one of which is for research that can directly or indirectly improve the quality of graduates who will be constrained if all are borne by students.

However, the implementation in the field related to BOPTN is often a hot scourge. One of them is the issue of the government that will make a policy regarding the reduction of the BOPTN budget at state universities. This policy was considered as a disaster for several parties. The most negative impact highlighted by the decline in the BOPTN budget is the rising cost of UKT for future new students. The government reduced the BOPTN budget not without reason. One of the reasons for the government in reducing this BOPTN budget is because the government allocates these funds to increase infrastructure development, especially in eastern Indonesia (Simamora, 2003).

This is evident from the 2015-2016 budget state budget at the budget ceiling set by the government, especially for the Ministry, Technology and Higher Education (Kemenristeksikti) which decreased by 3.2 trillion rupiahs, which in 2015 the budget ceiling for Kemenristekdikti was 42.7 trillion the rupiah becomes 39.5 trillion rupiah (apbn, 2016). Then it was strengthened by the circulation of news that member of the House of Representatives Commission X Nurhasan "encouraged the government to allocate 2016 BOPTN funds at least 5.5 trillion and channeled on time. BOPTN funds are expected to help ease the burden on students and parents in funding education in higher education " (Wibowo, 2012).

In connection with the situation in Banjarmasin City, the number of private and public tertiary institutions is a large group of education management organizations. Indeed, we are still prejudiced against the reality, where every university in the Banjarmasin has carried out optimalization and is quite good at its implementation. This can be proven by the existence of several universities that are favored by the community and the existence of several universities which are believed to be excellent universities (Sutrisno, I99I).

The allocation of BOPTN funds is faced with considerable challenges, especially in the field of budget management and control. In order to maintain the title of favorite and superior universities, managers must meet several needs both operational costs of education and fulfillment of the required infrastructure (Moleong, 2009).

The failure of the target in absorbing the budget will result in the loss of the benefits of spending. Because the funds that have been allocated apparently 
cannot be utilized optimally, which means there is iddle money. Whereas if the budget allocation is efficient, the limited sources of funds owned by the state can be optimized to fund strategic activities (Patton, 1990).

The phenomenon that often occurs in state universities that receive disbursement and BOPTN is that the BOPTN budget absorption is not optimal. Implementation in the field is often a complaint for state universities in optimizing the funds. The improper structuring also triggers the budget budget is not optimal (Winardi, 2003). This can have an impact on the performance of the person in charge of managing BOPTN funds who tend to be merely formalistic. As one of the state universities in Indonesia that received BOPTN funding from the government, Lambung Mangkurat University (ULM) suffered a similar fate (Partanto \& Pius, I994).

This research was carried out at the ULM Campus located on Jl. H. Hasan Basry Kelurahan Banjarmasin Utara, Banjarmasin City. The faculties on this campus are FEB, FISIP, FH, and the Teacher and Education Faculty. Besides the Faculty there are also several Postgraduate Programs at the Banjarmasin Campus. Starting from January 2019 until February 2019.

\section{Methodology}

This research is included in the type of Qualitative Research with the presentation of data that is descriptive in form through words and not a series of numbers.

This research was conducted on Banjarmasin ULM based on its existence which began to increase since it was ranked as the 8th PTN category in Indonesia in the public information disclosure held by the Central Information Commission in 2015. ULM also carved achievements as one of ten (I0) Center award recipients The superior science and technology (PUI) determined by the Ministry of Research, Technology and Higher Education.

The quantitative data are obtained from the documentation and interview results regarding BOPTN budget absorption data on FEB, FISIP, and ULM Banjarmasin Faculty of Law starting from the 2016 budget year to 2018 and other supporting data that are quantified through descriptive techniques. While qualitative data are in the form of interview data and observations. The data analysis technique used in this study is quantitative and descriptive qualitative analysis.

This primary data source researchers got through the results of interviews with the Treasurer of the ULM Banjarmasin BOPTN as coordinator and budget manager. Secondary data is usually in the form of documentation data or report data that is available. The secondary data in this study were taken from the Treasurer of the ULM Banjarmasin BOPTN as an informant, using the results of documentation in the form of data on the absorption of the 2016 S / D BOPTN budget for FEB, FISIP and FH.

\section{Result and Discussion}

The absorption of the budget in Banjarmasin ULM in 2016 is still unsatisfactory, indicated in table number one by the remaining nominal use of the budget which tends to be large and the percentage of realization of the use of funds towards the amount of list of budget execution (DIPA) funds that tends to be low. However, in the data of the last two years, the absorption carried out by each Banjarmasin ULM work unit experienced a significant increase.

In 2017, the FISIP work unit occupied a percentage figure of $99.99 \%$ budget realization. The figure that is almost $100 \%$ is a very good category. Until 2018, the absorption of BOPTN funds in the FISIP work unit reached $100 \%$ of the budget realization. This is a very good progress and needs to be maintained so that the absorption of Banjarmasin ULM BOPTN funds can be proportionally appropriate.

Based on several previous studies, the factors that influence budget absorption include the factors of budget planning, human resources (HR) and information technology factors. According to Halim (20I4), maximum budget absorption must also be followed by good budget planning. optimal budget absorption without good budget planning can be said as an impossible thing to be realized.

Budget planning will begin with initial submissions made by ministries and agencies which then lead to RKA-KL. The discussion and budgeting carried out can be said to be a recurring process in stages, although it may be different in the program and its implementation.

The planned program must be comprehensive and simultaneous, where each program has gone through an understanding and planning before entering into budgeting. A program is expected to be completed properly in one fiscal year, unless it is stated that the program will take time and multiple years. The more programs that are carried out in one budget period it will increase the absorption of the budget in one organization, ministry or institution. So that it can be said that the absorption of budget performance is close to the maximum. 
According to Herriyanto (2012), HR problems occur starting with reluctance and fear of being a procurement committee. This is because of the imbalance of workmanship risks with the rewards received. In addition, working as a committee is a side job in addition to the main work and daily routine, so it is less competent in carrying out the procurement of goods / services. This is a risk of delays in the process of goods / services procurement. Edinson (2017) in his book Human Resource Management states that to fulfill the element of competence, an employee must fulfill the elements below:

I. Knowledge: having knowledge gained from learning formally or from trainings or courses related to the field of work he is handling.

2. Skills (skills): have expertise in the field of work handled and are able to handle it in detail. However, besides experts, he must have the ability to solve problems and solve them quickly and efficiently.

3. Attitude: uphold organizational ethics, and have a positive attitude (friendly and polite) in acting.

Based on the theory above, an employee who does not have the knowledge obtained through formal study or has knowledge obtained by Lewt to study formally or has knowledge but is not related to the field of work he is handling, so that he does not have the required competence in his field will have an impact on the performance of the employee concerned.

Another thing that affects budget absorption is the use of information technology. Technology is seen as a tool used by individuals to complete their tasks. The obligation to use information technology by the Government and Regional Governments is regulated in Government Regulation No. 56 of 2005 concerning Regional Financial Information Systems which is a substitute for PP No. II of 200I.

Although in general there have been many known benefits offered by an information technology including transaction processing speed and report preparation, calculation accuracy, large amounts of data storage, lower processing costs, multiprocessing capabilities (Wahana Komputer, 2003), but the implementation of information technology not cheap. Moreover, if existing information technology is not or has not been able to be fully utilized, the implementation of technology becomes futile and increasingly expensive.
Obstacles to the application of information technology include the condition of hardware, software used, updating of data, conditions of existing human resources, and limited funds. These constraints, among others, are not yet optimal factors in the utilization of information technology in government agencies.

The use of information technology according to Thomas et al. in Tjhai (2003) is a benefit expected by users of information systems in carrying out their duties or behavior in using technology when doing work. The measurement is based on the intensity of utilization, and the number of applications or software used. The proper use of information technology and the expertise of the personnel who operate it can improve the performance of the institution and the performance of the individual concerned.

The use of information technology by higher education institutions has become a necessity in the current global market, even universities that are ranked as the top rank universities place the main management units of business processes and academic processes and institutional decision making in relation. Universities that have used information technology to the fullest will usually find it difficult to compete with their comets.

Actually the development of information technology now provides many conveniences on various aspects of organizational activities. Information technology has brought very basic changes to organizations both private and public organizations. Therefore, information technology is very important in determining competitiveness and the ability of organizations to improve performance in the future.

Information technology resources become a consideration for leaders of private and public organizations in determining future success. Considering the role of information technology in the future, the government through intense ministries / agencies adopts information technology (hardware and software) tools into administrative governance towards e-government governance.

Gomes (1995) mentions that all potential resources humans are very influential towards the efforts of the internal organization achievement of his goal. However advancement in technology, development information, but if without resources humans it will be difficult for the organization to reach his goal. By hence human resources work with all abilities, skills, that knowledge it will be effective for achievement organization goals. For the government, the goal what you want to achieve is welfare the community, whose achievements carried out through budget absorption. 
Husein et. al, (2005) stated that the development of e-govement is a transformation process from manual to electronic, so systematic efforts are needed regarding the subject, object and method associated with the transformation process. This transformation process refers to three things, namely legislation in the field of technology and communication, current conditions, and environmental influences that originate from the demands of public services and the advancement of information and communication technology.

The context of the constraints of information technology in Indonesia found that the technological infrastructure constraints in Indonesia consisted of (I) information technology hardware generally consisting of personal computers that were connected to the internet network but the interconnection to the internet is still a simple configuration seen from the small number of institutions that use network security or network management. (2) in terms of infrastructure development, there are still many institutions that use external consultants for development, this indicates that there is still inadequate information technology capabilities.

In relation to the end of human resources in the field of information technology, it was found that the availability of human resources in the field of information technology was the main obstacle faced by institutions, most likely related to the pattern of development of information technology human resources that were less attractive to quality people.

The survey results and observations of the respondents on the answers of the respondents concluded that the management of the Banjarmasin
ULM budget could not be separated from the utilization of information technology both hardware and software. This can be seen from the respondent's contents of the questions the author asks where it can be concluded that budget management activities starting from the data collection of proposed budget for each work unit, both income and expenditure plans to the preparation of budget planning and implementation documents cannot be separated from information technology that is, most of the process uses the help of computers, the internet and applications (software).

However, the role of information technology that is so important in the budget process as in the facts above is not followed by the condition of internet services and the schedule of maintenance / improvement of information technology devices.

Hardware and software maintenance and repairs are compiled in a comprehensive, clear and periodic manner. even though a computer set will not help a lot of work tasks if it is not supported by devices such as printers, scanners, and adequate internet networks. Such conditions cause our frequent viewing of computers, printers, monitors, and other equipment that are piled up in the corner of the room left in a state of damage and not repaired.

The intermittent condition of internet services along with the lack of maintenance and improvement of information technology devices such as computers, printers, internet networks and so on, certainly affected employee performance, including the budget performance of Banjarmasin work units and ULM in general.

Table I. Year 2016

\begin{tabular}{llcccc}
\hline No & Work Unit & Budget Ceiling & Budget Realization & $\begin{array}{c}\text { The Remaining } \\
\text { Budget }\end{array}$ & Percentage \\
\hline I. & FEB & 4II.360.000 & 372.366 .000 & 38.994 .000 & $90,52 \%$ \\
2. & FISIP & 321.040 .000 & I8I.038.000 & 140.002 .000 & $56,39 \%$ \\
3. & FH & 245.000 .000 & I55.04I.230 & 89.958 .770 & $63,28 \%$ \\
\hline
\end{tabular}

Table 2. Year 2017

\begin{tabular}{llcccc}
\hline No & Work Unit & Budget Ceiling & $\begin{array}{c}\text { Budget } \\
\text { Realization }\end{array}$ & $\begin{array}{c}\text { The Remaining } \\
\text { Budget }\end{array}$ & Percentage \\
\hline I. & FEB & $4 \mathrm{II} .360 .000$ & $392.2 \mathrm{I} 4.532$ & 19.145 .468 & $95,35 \%$ \\
2. & FISIP & 321.040 .000 & 321.019 .000 & 21.000 & $99,99 \%$
\end{tabular}



3. $\mathrm{FH}$
245.000 .000
243.500 .000
1.500 .000
$99,39 \%$

Table 3. Year 2018

\begin{tabular}{llcccc}
\hline No & Work Unit & Budget Ceiling & Budget Realization & $\begin{array}{c}\text { The Remaining } \\
\text { Budget }\end{array}$ & Percentage \\
\hline I. & FEB & 583.800 .000 & 551.424 .092 & 32.375 .908 & $94,45 \%$ \\
2. & FISIP & 372.650 .000 & $372.632 .2 \mathrm{I} 4$ & 17.786 & $100,00 \%$ \\
3. & FH & 245.000 .000 & 243.000 .000 & 2.000 .000 & $99,18 \%$ \\
\hline
\end{tabular}

\section{Conclusion and Recommendation}

Budget absorption in the FEB, FISIP, and FH ULM Banjarmasin units from 2016-2018 experienced a significant increase in BOPTN fund absorption optimization. This is intended from the percentage figures in the recapitulation of budget realization in the FEB, FISIP, and FH ULM work units that reached $\mathrm{I00} \%$ in 2017 and 2018.

Employee competencies and budget absorption performance have a unidirectional relationship, if employee competencies are higher, the higher the absorption rate of the budget will be. Similarly, the role of information technology is so important in the budget process. Maintenance and repair of hardware and software that are compiled in a comprehensive, clear and periodic manner. Because a computer set alone will not help a lot of work tasks if it is not supported by devices

such as printers, scanners, and adequate internet networks. In order to improve optimization of the absorption of the budget, it should Commitments that will encourage self-confidence, and work spirit carry out the task towards change in a better direction. Care and maintenance of the media and other supporting tools must be considered again, before and after use to be stored in the proper place. Administration or secretariat should receive more attention, so that the storage of records, documentation and other files remain in neat and well-maintained condition.

\section{Acknowledgment}

Authors thanks to Education Management Masters Program, Lambung Mangkurbat University, Banjarmasin for supporting this research.

\section{References}

Bastian, I. (2006). Educational Accounting. Yogyakarta: Erlangga.
Moleong, L. (2009). Qualitative Research Methodology. Bandung: PT Remaja RosdaKarya.

Partanto, A, \& Pius, (1994). Popular Scientific Dictionaries. Surabaya: Arkola.

Patton, M. Q. (1990). Qualitative Evaluation and Research Methods, 2nd Ed. Thousand Oaks, CA: Sage Publications.

Republic of Indonesia. (2016). Regulation of the Minister of Research, Technology and Higher Education of the Republic of Indonesia number 6 of 2016 concerning Higher Education Operational Assistance. Article I. State Gazette of the Republic of Indonesia in 2016, No. 226. State Secretariat, Jakarta.

Saifuddin, A. (2007). Research Methods. Yogyakarta: Student Library Cet. VIII.

Simamora, B. (2003). Performance Assessment in Company Management. Jakarta: Gramedia Library.

Suharsimi, A. (2013). Research Procedure: An Practice Approach. Jakarta: Rineka Cipta.

Sutrisno, H. (I99I). Item Analysis for Instrument. First edition. Andi Offset. Yogyakarta.

Wibowo. (2012). Performance Management. Jakarta: PT RajaGrafindo Persada.

Winardi. (2003). Organizational and Organizational Theory. Jakarta: PT RajaGrafindo Persada. 